\title{
Religious Tolerance and Freedom of Prophesying
}

\section{Social and Intellectual Interrelations between the Polish Brethren and the Collegiants in Seventeenth-Century Amsterdam}

\author{
Francesco Quatrini | ORCID: 0000-0002-2365-0415 \\ Vrije Universiteit Amsterdam, Amsterdam, The Netherlands \\ f.q.quatrini@vu.nl
}

\begin{abstract}
This essay focuses on the presence of Polish Brethren (usually known as Socinians) exiles in Amsterdam in the mid-seventeenth century, examining the social and intellectual interrelations between them and other Dutch religious minorities. It describes the phenomenon of the Brethren's emigration to the United Provinces, roughly between 1638 (when the Socinians were banished from Raków) and the late 166os, relying on both published and manuscript sources. It particularly emphasizes the social relations that the Brethren established with the Remonstrants, the Mennonites, and the Collegiants. It then focuses on the last group and argues that shared views on religious tolerance were the common intellectual ground that likely contributed to the friendly relationships between the Brethren and the Collegiants. It also argues that these relationships fostered further intellectual crossovers between the two groups, as the Brethren in Amsterdam were influenced by the Collegiants' emphasis on freedom of prophesying, egalitarianism, and anti-confessionalism.
\end{abstract}

\section{Keywords}

Socinianism - the Dutch Republic - Johannes Crell - religious exiles - networks family relationships - cross-confessional interactions - the early Enlightenment 
The early modern period was marked deeply by the phenomenon of religious emigration and exile. Following the fall of Constantinople in 1453, multitudes escaped from the Byzantine Empire looking for refuge in Europe, especially in Italy. The Iberian monarchies issued edicts of expulsion first against Jews and Muslims and then against the conversos. In Central Europe, the Thirty Years War and the wars afflicting Poland in the mid-seventeenth century forced entire Ashkenazic Jewish communities to wander through several countries, seeking a safe refuge. As for the Christian world, it goes without saying that emigration became a widespread phenomenon once the Reformation took root. Because of post-Reformation Europe's confessionally divided landscape, religious communities that thrived in some places could suffer religious persecution in others; those who controlled public pulpits in one region could be unwanted "sectarians" or "heretics" in another. Thus, it was not uncommon in the early modern era for Christians to be forced to leave their homes and look for another place where they could exercise their faith more safely. ${ }^{2}$ To be sure, dissenters' emigration was not the only solution to the confessional divide. Benjamin Kaplan has described forms of toleration practiced either locally or on a national level that ensured a more or less peaceful coexistence among people of different confessions. ${ }^{3}$ When facing an official ban enforced by civil authorities, however, death, Nicodemism, or exile were the only choices.

1 The research upon which this essay is based was conducted as part of the research project "War and the Supernatural in Early Modern Europe," funded by the European Research Council under the European Union's Horizon 2020 research and innovation programme (grant agreement number no. 67749o). I would like to thank Queen's University Belfast as the host institution of this research project and Ian Campbell for his comments and suggestions on a earlier draft of the paper.

2 Among the many studies on religious exiles, see Yosef Kaplan, The Western Sephardic Diaspora (Tel Aviv, 1994); Heiko A. Oberman, John Calvin and the Reformation of the Refugees (Geneva, 2009); Jesse Spohnholz and Gary Waite, eds., Exile and Religious Identity, 1500-1800 (London, 2014); Nicholas Terpstra, Religious Refugees in the Early Modern World (Cambridge, 2015); Timothy G. Fehler, Religious Diaspora in Early Modern Europe: Strategies of Exile (London, 2016); Yosef Kaplan, ed., Early Modern Ethnic and Religious Communities in Exile (Newcastle upon Tyne, 2017); Violet Soen, Alexander Soetaert, Johan Verberckmoes, and Wim François, eds., Transregional Reformations: Crossing Borders in Early Modern Europe (Göttingen, 2019).

3 Benjamin Kaplan, Divided by Faith: Religious Conflict and the Practice of Toleration in Early Modern Europe (Cambridge, MA, 2007), 125-234. Following Kaplan's definitions, I use the term "tolerance" to refer to the concept of toleration and "toleration" to refer to the social practices of peaceful interaction among people belonging to different confessions. Ibid., 8. Practices of coexistence between different confessions are described also by historian Willem Frij- 
This is what happened, for instance, to the Minor Church of Poland or Polish Brethren - better known as Socinians, named after the Italian refugee Faustus Socinus (or Sozzini) (1539-1604), who contributed greatly to the shape of the Brethren's ideology. ${ }^{4}$ The Minor Church was born from a schism within the Reformed Church of Poland, when some of its ministers began defending antiTrinitarian beliefs and holding socio-political views influenced by the Moravian Anabaptists. Despite being anti-Trinitarians, and thus being regarded as worse than Jews and Muslims, Brethren communities flourished in the PolishLithuanian Commonwealth, thanks to the protection given by Polish lords such as Mikołaj Sienicki and the Sienieński family and, more generally, to the culture of toleration characterizing the Commonwealth. Acts of violence and persecution against Protestant denominations, however, increased in the course of the seventeenth century. These and an active campaign against religious tolerance gradually led to the formal banishment of the Brethren from the Commonwealth in 1658 , officially prompted by their siding with the Swedish king during the Second Northern War (1655-166o). Twenty years earlier, the Brethren had already suffered a major blow against their community: the destruction of their stronghold in Raków in $1638 .{ }^{5}$

hoff, who coined the concept of omgangsoecumene ("ecumenicity of everyday life"). See, for example, Willem Frijhoff, "Dimensions de la coexistence confessionnelle," in The Emergence of Tolerance in the Dutch Republic, ed. C. Berkvens-Stevelinck, J. Israel, and G.H.M. Posthumus Meyjes (Leiden: Brill, 1997), 213-238; also see Willem Frijhoff and Marijke Spies, 1650: HardWon Unity [Dutch Culture in a European Perspective 1] (Assen, 2004).

4 For the use of the names "Brethren" and "Socinian," see Piotr Wilczek, Polonia Reformata: Essays on the Polish Reformation (Göttingen, 2016), 39.

5 For more information on the history and ideology of the Polish Brethren, see Stanisłas Kot, Socinianism in Poland: The Social and Political Ideas of the Polish Antitrinitarians, trans. Earl Morse Wilbur (Boston, 1957); Earl Morse Wilbur, A History of Unitarianism: Socinianism and Its Antecedents (Cambridge, MA, 1945), 281-430; Lech Szczucki, ed., Faustus Socinus and His Heritage (Kraków, 2005); Mariangela Priarolo and Emanuela Scribano, Fausto Sozzini e la filosofia in Europa (Siena, 2005); Delio Cantimori, Eretici italiani del Cinquecento e Prospettive di storia ereticale italiana del Cinquecento, ed. Adriano Prosperi (Torino, 20o9), 312-418; Sarah Mortimer, Reason and Religion in the English Revolution: The Challenge of Socinianism (Oxford, 2010), 1-38; Sasha Salatowski, Die Philosophie der Sozinianer: Transformationen zwischen Renaissance-Aristotelismus und Frühaufklärung (Stuttgart-Bad Cannstatt, 2015); Wilczek, Polonia Reformata (see above, n. 4), 45-92. For more information on the culture of tolerance in sixteenth-century Poland, see Wiktor Weintraub, "Tolerance and Intolerance in Old Poland," Canadian Slavonic Papers / Revue Canadienne des Slavistes 13, no. 1 (1971), 2144; Michael G. Müller, "Protestant Confessionalisation in the Towns of Royal Prussia and the Practice of Religious Toleration in Poland-Lithuania," in Tolerance and Intolerance in the European Reformation, ed. Ole Peter Grell and Bob Scribner (Cambridge, 1996), 262-281; Wojciech Kriegseisen, "Historical Overview of the Political and Denominational Reality in the Polish-Lithuanian Commonwealth from the Mid-Sixteenth Century to the Mid-Seventeenth 
Between 1658 and 166o, therefore, the Brethren gradually left their homeland. ${ }^{6}$ Many moved into those regions where they had already established churches or where there were other anti-Trinitarian communities, such as Brandenburg, East Prussia, and Transylvania, while others reached the Netherlands. ${ }^{7}$ This is hardly surprising. Although the majority of Dutch citizens did not regard religious toleration as a positive value, but rather "as an unforeseen and unfortunate result of the Reformation and the Dutch Revolt," it is undeniable that the seventeenth-century Dutch Republic was a shelter for many dissenters. ${ }^{8}$ Members of many different Christian denominations lived and worked together on a daily basis in the United Provinces, where the quest for concordia - that is, "harmony," "concord," or "agreeing together" - was at the centre of the Dutch political discourse at the time. ${ }^{9}$ Therefore, despite the fierce opposition of the Dutch Reformed Church to anti-Trinitarian beliefs, Brethren exiles managed to find refuge in the Netherlands, especially in Amsterdam.

This paper examines the phenomenon of the Brethren's exile in Amsterdam roughly between the late 163 os and 166 os from a social and intellectual perspective. Relying on both contemporary studies and new archival material, it emphasizes how higher numbers of Brethren settled in Amsterdam only after 1658 , relying on family relations and on the tolerant attitude of other religious groups that welcomed the Brethren into their circles. Then, it reveals how these social relations were enabled by common intellectual views and how they promoted further intellectual interrelations among these groups. To prove this, it focuses particularly on one of the Christian groups that welcomed the Brethren in their circles, the Dutch Collegiants, who shared the Brethren's views on religious tolerance and whose practices influenced the views of the Brethren

Century," in Word of God, Words of Men: Translations, Inspirations, Transmissions of the Bible in the Polish-Lithuanian Commonwealth in the Renaissance, ed. Joanna Pietrzak-Thébault (Göttingen, 2019). For the Second Northern War, see Robert I. Frost, After the Deluge: PolandLithuania and the Second Northern War 1655-1660 (Cambridge, 1993).

6 Marian Hillar, "Poland's Contribution to the Reformation: Socinians and Their Ideas on Religious Freedom," The Polish Review 38 (1993), 458-459.

7 Wilbur, History of Unitarianism (see above, n. 5), 1:483-522. For more information on the preexistent anti-Trinitarian communities in Transylvania, see Mihály Balász, Early Transylvanian Antitrinitarianism, 1566-1571: From Servet to Palaeologus, transl. György Novák (Baden, 1996); Cantimori, Eretici Italiani (see above, n. 5), 312-322 and 40o-406.

8 J.van Eijnatten, Liberty and Concord in the United Provinces: Religious Toleration and the Public in the Eighteenth-Century Netherlands (Leiden, 2003), 3. Here quoted from Wiep van Bunge, "'Concordia res parvae crescunt': The Context of Seventeenth-Century Dutch Radicalism," in The Dutch Legacy: Radical Thinkers of the 17th Century and the Enlightenment, ed. Sonja Lavaert and Winfried Schröder (Leiden, 2017), 20.

9 Ibid., 20-21. See also Frijhoff and Spies, 1650 (see above, n. 3). 
on concepts such as anti-confessionalism, freedom of prophesying, and egalitarianism. Therefore, while contributing to existing studies on the Brethren's emigration from Poland-Lithuania, this paper combines two usually distinct approaches to the history of early modern Europe, one focusing on social networks and practices, and the other one on the history of ideas, revealing how there is an interconnection between them: practices, networks, and ideas were all mutually implicated in their development.

\section{$2 \quad$ The Polish Brethren in Amsterdam}

The history of the Brethren in the Dutch Republic begins well before their banishment from Poland in 1658. Indeed, in August 1598, two Brethren missionaries, Andrzej Woidowski (1565-1622) and Christopher Ostorodt (c. 156o-1611), reached Amsterdam, carrying Socinus's and other Brethren books with them. From Amsterdam they moved to Leiden, in the hope of making converts among the university students. Reformed ministers and theologians teaching at the University of Leiden, however, strongly opposed Woidowski and Ostorodt, judging the Brethren's faith to be a sort of "Turkish heresy," as stated in a resolution from the States General dated 8 September $1598 .{ }^{10}$ The two Brethren were soon expelled from the Dutch Republic and most of the books they were carrying were publicly burned. They had succeeded, however, in making the Brethren's beliefs known in the Netherlands. Charges of Socinianism - the name given to the Brethren's ideology-became common in theological disputes. Counter-Remonstrants, for instance, often accused the Remonstrants of being Socinians. Even in the Doopsgezind (i.e., "Mennonite") communities, charges of Socinianism were made between opposing parties in the 1620 s. $^{11}$

Fears that multitudes of Polish anti-Trinitarian exiles would invade the Republic spread among ecclesiastical and civil authorities around 1638, when the Brethren were banished from Raków. It should be emphasized, however,

10 W.J. Kühler, Het socinianisme in Nederland (Leiden, 1912), 55 .

11 For more information on the role played by the Brethren's ideas in the controversy between Remonstrants and Counter-Remonstrants, see ibid., 57-9o; Johnathan Israel, The Dutch Republic: Its Rise, Greatness, and Fall 1477-1806 (Oxford, 1995), 421-477; Sarah Mortimer, "Human Liberty and Human Nature in the Works of Faustus Socinus and His Readers," Journal of the History of Ideas 70 (2009): 197-211. On the debates among the Doopsgezinden, see Gary Waite, "The Drama of the Two-Word Debate among Liberal Dutch Mennonites, c. 1620-166o: Preparing the Way for Baruch Spinoza?" in Radicalism and Dissent in the World of Protestant Reform, ed. Bridget Heal and Anorthe Kremers (Göttingen, 2017), 118-135. 
that such fears had no actual basis, as there is no evidence of large numbers of Polish or German anti-Trinitarians settling in the Netherlands either before or around 1638. Indeed, when leaving Raków, most of the Brethren scattered across the already existing communities in Poland and Lithuania. ${ }^{12}$ The news coming from Poland, however, triggered such fears; these were then further amplified by the discovery of a letter sent by Jan Stoinsky (Stoinius or Statorius), a minister of the Polish Minor Church who was living in Amsterdam in 1638, apparently recovering from a serious illness.

Writing to Adam Francke (Franck or Francus) (1595-1655), minister of the German anti-Trinitarian church in Kolosvár (Transylvania), Stoinsky explained that in the Republic there were many opponents of the Brethren's faith, but that there was also "a great harvest," as many intellectuals were secretly antiTrinitarians. Stoinsky's letter, however, never reached Francke. It was intercepted in Transylvania by a Calvinist prince and sent to Utrecht. It was then translated into Dutch and quickly spread all over the Netherlands as a warning against the coming of Brethren exiles. Indeed, Stoinsky's words were interpreted as if the Brethren from Raków were planning to move to the United Provinces. ${ }^{13}$ This, of course, alarmed the Reformed Church.

In two consistory sessions in Amsterdam, held on 7 October and 18 November 1638, the Reformed ministers reported the news coming from Poland. The "Socinians" had been banished from Raków and from Transylvania (which was not true), they were looking for a new place where they could exercise their faith, and thus, they might very well decide to settle in Amsterdam. ${ }^{14}$ This news preceded Stoinsky's letter, which came to the attention of the kerkenraad on 17 March $1639 .{ }^{15}$ Knowing that the letter had been sent by a certain "Johannes Sartorius" (that is, Statorius), the Reformed consistory began to investigate his whereabouts and they soon discovered that he was living in Amsterdam. ${ }^{16}$

12 Wilbur, History of Unitarianism (see above, n. 5), 1: 454-457.

13 Kühler, Socinianisme (see above, n. 10), 137; Wilbur, History of Unitarianism (see above, n. 5), 1: 551-553; Israel, Dutch Republic (see above, n. 11), 910; Atilla Kis, "Enkele contacten van Transsylvaanse unitariërs met de zeventiende- en achttiende-eeuwse Nederlandse samenleving," Doopsgezinde Bijdragen 30 (2004), 193-194. Kis's paper is part of a collection of essays on Socinianism in the Netherlands published as a special issue of the Dutch journal Doopsgezinde Bijdragen. See Socinianisme in de Nederlanden, Doopsgezinde Bijdragen 30 (2004).

14 Amsterdam City Archive (Stadsarchief Amsterdam), access no. 376, Archief van de Hervormde Gemeente, Kerkenraad, inventory no. 7 (hereafter cited as ACA 376/7), fols. 266 and 271.

15 ACA $376 / 7$, fol. 287 .

16 ACA $376 / 7$, fol. 288 . 
The consistory then decided to appeal to the civil authorities, but on 14 April, they discovered that Stoinsky had already left Amsterdam and returned to Poland. ${ }^{17}$ In the following weeks, Dutch authorities remained vigilant on this whole matter, as sometime before June 1639 the English resident ambassador in the Dutch Republic, William Boswell, warned the States General that many Socinian exiles were planning to reach the United Provinces from Gdańsk. ${ }^{18}$ However, this "invasion" of Socinian exiles, so much feared, occurred neither in 1639 , nor in the following years.

Some families of Brethren coming from Poland would settle in the United Provinces only from the late 165 os onward. This might seem surprising when one considers that the Reformed Church had strongly opposed the spreading of the Brethren's ideology in the preceding years. A growing anti-Socinian campaign started in the United Provinces in the early 1640s and the edict against Socinianism enacted by the States of Holland in September 1653 is a clear example of the outcome of this campaign. ${ }^{19}$ It is clear, however, that if such a campaign ever managed to limit the spread of the Brethren's ideas (which one can very much doubt), it had no effect on restraining Socinian emigration to the Netherlands once the Brethren were banished from Poland in $165^{8}$. Indeed, a number of Brethren managed to settle in Amsterdam thanks to their family relations and their contacts with other Christian groups, particularly the Remonstrants and the Collegiants.

On 13 April 1662, the Reformed ministers reported to the consistory that the socinianen had been banished from Poland and might move to Amsterdam, spreading their heretical errors. ${ }^{20}$ It is somewhat surprising that the Amsterdam kerkenraad discussed this only four years after the official ban against the Brethren. Perhaps news of the ban had not reached the Reformed Church of Amsterdam or, more likely, the threat of Socinianism was not the primary concern of the Reformed ministers in those years. The situation, however, changed in 1662, when one of the Brethren living in Amsterdam since 1657, Daniel Zwicker (1612-1678), came under the lens of the Reformed Church because of one of his books, the Irenicum irenicorum, which was charged with violating the edict against Socinianism. ${ }^{21}$ The renewed fear of the Reformed ministers

\footnotetext{
17 ACA $376 / 7$, fols. 289,29 o, and 291.

18 Amsterdam City Archive, access no. 1120, Archief van Verenigde Doopsgezinde Gemeente van Amsterdam, inventory no. 1043, fol. 83 .

19 Kühler, Socinianisme (see above, n. 10), 137-138; Israel, Dutch Republic (see above, n. 11), 909-916.

20 ACA 376/10, fol. 253. The Reformed ministers made similar statements in the following weeks: ibid, fols. 254,255 , and 258 .

21 Ruud Lambour, "De familie and vrienden van Daniel Zwicker (1612-1678) in Amsterdam,"
} 
for the arrival of exiled anti-Trinitarians in 1662 was thus likely related to the concerns regarding Zwicker's activities. Indeed, the history of the Brethren in the late seventeenth century developed around networks underpinned by family relationships, and Zwicker was related to the most famous families among the Brethren, as Ruud Lambour has extensively documented. ${ }^{22}$

Zwicker was married to Catharina Voss, daughter of Martin Voss, merchant and council member of the city of Gdańsk. Maria Voss, Catharina's sister, was Marcin Ruar's wife and thus, Zwicker was Ruar's brother-in-law. ${ }^{23}$ Marcin Ruar (1589-1657) had been a central figure among the Brethren since the 162os. Indeed, through his frequent travels abroad and his extensive correspondence, he became the chief architect of the Brethren's international network. ${ }^{24}$ Ruar was also related to the Stegmann and Crell families. His daughter Margaretha married Johannes Crell Jr., third son of the very famous Johannes Crell (15901633). ${ }^{25}$ Another daughter of Ruar, whose name is unknown, married Joachim Stegmann Jr., son of Joachim Stegmann $\left(1595^{-1633)} \cdot{ }^{26}\right.$ All these Brethren gradually moved to Amsterdam in the 166os. Martin Voss joined his son-in-law and daughter at the end of $1663 .{ }^{27}$ Marcin Ruar's widow (Ruar died in 1657) moved to Amsterdam together with his daughter Margaretha and Joahnnes Crell Jr. sometime before 5 September $1664{ }^{28}$ They were then followed by Ruar's three sons, Joachim, Marcin, and David (in Amsterdam around 1665 and 1668), and his other three daughters. Joachim Stegmann Jr. and his wife moved to Amster-

Doopsgezinde Bijdragen 25 (1999), 113-166, there 113. There are numerous reports about Zwicker in the minutes of the Amsterdam kerkenraad starting from February 23, 1662. See the entry "Sosiniaens boeck Zwickerus" in ACA 376/10. For more information on Zwicker, see, Peter G. Bietenholz, Daniel Zwicker (1612-1678): Peace, Tolerance and God the One and Only (Florence, 1997). Following Biethenholz, I have not translated the title of Zwicker's work Irenicum irenicorum. The reason is that this title is a word pun, likely used by Zwicker to suggest his preeminence over other irenicist authors of the time, and an English translation would hardly render Zwicker's intended meaning. For more on this issue, see ibid., 56 .

22 Martin Mulsow, "Transnational Dissidence: Samuel Crell's Socinian Exile," in Ethnic and Religious Communities (see above, n. 2), 98 and 114; Lambour, "Daniel Zwicker" (see above, n. 21); Ruud Lambour, "Aanvullingen op het onderzoek naar het Amsterdamse milieu van Daniel Zwicker (1612-1678)," Doopsgezinde Bijdragen 26 (2000), 53-66.

23 Lambour, "Daniel Zwicker" (see above, n. 21), 117 and 124.

24 A comprehensive study of Ruar's contributions to the history of the Polish Brethren and his role within the Republic of Letters is still lacking.

25 Lambour, "Daniel Zwicker" (see above, n. 21), 124. Other members of the Crell family settled in Amsterdam since the early 1670 onwards. Ibid., 129-133.

26 Ibid., 124.

27 Ibid., 118 and 122.

28 Ibid., 124. 
dam in $1666 .{ }^{29}$ Another Brethren family that gradually settled in Amsterdam was the Ladenbach family. Andreas Ladenbach (Ladenbeek or Laanbeek) married Zwicker's sister Susanna in 1639 in Gdańsk and moved to Amsterdam in 1658, where their sons Benjamin and Christiaan joined them respectively in 1663 and $1672 .^{30}$

Brethren related to Daniel Zwicker were not the only ones moving to Amsterdam in the 166os. Andreas Wissowatius (1608-1678), grandson of Faustus Socinus, moved to Amsterdam in 1666 around the same time that Stegmann Jr. and his wife were settling there. In the following years, other members of the Wissowatius family joined him in Amsterdam. ${ }^{31}$ Christopher Sandius (16441680), author of the posthumously published Bibliotheca anti-Trinitariorum [The Anti-Trinitarians's Library], moved to Amsterdam in $1669 .{ }^{32}$ There is evidence proving that Sandius had a close relationship with Baruch Spinoza (1632-1677) in the last years of the philosopher's life, and Spinoza also owned two copies of Sandius's Nucleus historiae ecclesiasticae [The Kernel of Ecclesiastical History]..$^{33}$ Adam Francke Jr. (1639-1712) (son of Adam Francke, who corresponded with Stoinsky in 1638) was another renowned member of the Brethren who moved to Amsterdam around 1664. Francke Jr., however, was not an exile. Coming from Transylvania, he studied theology at the University of Leiden and afterwards he did not return to his homeland, but decided to settle in Amsterdam instead. He was in close relationship with Samuel Przypkowski $(1592-1670)$ and there is evidence showing that Francke was financially supported by Stanisław Lubieniecki $\left(1623^{-1675)}\right)^{34}$

Amsterdam was not only a refuge for anti-Trinitarian exiles coming from abroad, but also for those expelled by their own communities within the Republic. This was the case, for instance, of Johannes Becius. Becius was a follower of Zwicker, who reached Amsterdam in 1668, after being banished from Middelburg and after fleeing from Rotterdam. ${ }^{35}$ On 23 August 1668, the Amsterdam kerkenraad discussed the presence of Becius in the city. Having

29 Ibid., $125^{-128 .}$

$30 \quad$ Ibid., 133-136.

31 Ibid., 128 and 163-165; Lambour, "Aanvullingen" (see above, n. 22), 65-66.

32 Lambour, "Daniel Zwicker" (see above, n. 21), 149.

33 Lech Szczucki, "W kręgu spinozjańskim:(Krzysztof Sandius junior)," Przegląd FilozoficznoLiteracki 6, no. 3-4 (2007), 289-311; Mogens Laerke, "G.W. Leibniz's Two Readings of the Tractatus Theologico-Politicus," in Spinoza's Theological-Political Treatise: A Critical Guide, ed. Yitzhak Y. Melamed and Michael A. Rosenthal (Cambridge, 2010), 113.

34 Attila Kis, "De brief van Adam Francke, geschreven in Amsterdam, 15 februari 1667," Doopsgezinde Bijdragen 25 (1999), 197-199.

35 Lambour, "Daniel Zwicker" (see above, n. 21), 117 and 149. 
received information from the Reformed Church of Middelburg, where Becius was born and where he worked as a schoolmaster in the Latin school, the ministers explained that Becius served as a Reformed preacher at the Brabantse Olijfberg church in Antwerp. However, he then yielded first to Remonstrant and then to Socinian errors. He had published a book full of Socinian heresies and the civil magistrate expelled him from Middelburg for this reason. ${ }^{36}$ In January 1672, the Amsterdam kerkenraad showed some interest in Becius again. Members of the Reformed Church spoke with him about the Socinian heresy. Becius had complained about his treatment by the Middelburg kerkenraad and thus, the Amsterdam consistory hoped that they might be able to win him back to the Reformed cause. ${ }^{37}$ There are no further minutes discussing Becius's case, but since he remained active in Socinian and Collegiant circles, it is clear that consistory's hopes were in vain.

The presence of family members already settled in the city was clearly a major stimulus for the gradual emigration of Brethren who were moving to Amsterdam during the 166 os. $^{38}$ The contacts with other religious groups was another factor that favoured the Brethren's emigration to Amsterdam. Ties between the Brethren and leading Remonstrants, for instance, had strengthened during the 1640 os and 1650 s, as proven by the many letters exchanged among them. ${ }^{39}$ Once in Amsterdam, many Brethren became members of the Remonstrant congregation. For instance, Martin Voss, Maria Voss, his daughter Margaretha, and Johannes Crell Junior registered in the Remonstrant church of

$36 \quad$ ACA $376 / 11$, fol. 402 .

37 ACA 376/12, fol. 210. See also: ACA 376/12, fol. 208.

38 Another major stimulus might have been the prospect of working in the printing and book-selling sectors. Indeed, many of the names mentioned so far are known as editors for the Brethren's writings or as booksellers. For many Brethren, besides economic reasons, working in these sectors likely also meant keeping alive their forefathers' ideology. See, for instance, Piet Visser, “'Blasphemous and Pernicious': The Role of Printers and Booksellers in the Spread of Dissident Religious and Philosophical Ideas in the Netherlands in the Second Half of the Seventeenth Century," Quaerendo 26, no. 4 (1996), 303-326.

39 These letters were partially published during the seventeenth century. See Piet Visser, ed., Bibliographia Sociniana: A Bibliographical Reference Tool for the Study of Dutch Socinianism and Antitrinitarianism, compiled by Philip Knijff and Sibbe Jan Visser (Hilversum, 2004), 67-69 and 9o. Johannes Naeranus was one of the Remonstrants who had close relationships with the Brethren. He knew leaders such as Joahnnes Crell, Marcin Ruar, and Andreas Wissowatius, and he took active part in the publication of the famous Bibliotheca Fratrorum Polonorum together with Adam Francke Jr. and Frans Kuyper. Lambour, "Aanvullingen" (see above, n. 22), 54; Kis, "Adam Francke" (see above, n. 34), 198. For more information on Johannes Naeranus, see Sibbe Jan Visser, Samuel Naeranus (1582-1641) en Johannes Naeranus (1608-1679): Twee remonstrantse theologen op de bres voor godsdienstige verdraagzaamheid (Hilversum, 2011). 
Amsterdam once they settled in the city. ${ }^{40}$ The Remonstrant Church was clearly willing to offer protection to the anti-Trinitarian exiles coming from Poland and Lithuania. Relationships were established also with the DoopsgezindMennnonite congregations. Catharina, Christina, and Maria Ruar, for instance, married members of the Waterlander congregation, while Johannes Crell Jr. began attending the services of the Waterlanders once he moved to Zaandam in $1669 .{ }^{41}$

Moreover, by the early 166 os, the Amsterdam Collegiants had been meeting somewhat regularly for more than ten years. In these meetings, they practiced toleration, egalitarianism, and freedom of prophesying, that is, freedom to interpret passages of the Scripture and to express one's opinions on the matters under discussion, however unorthodox they might be. ${ }^{42}$ Some of the Collegiants in Amsterdam, such as Daniel de Breen (1594-1664), Jan Knol (d. 1672), and Frans Kuyper (d. 1691), were also openly anti-Trinitarians. ${ }^{43}$ Once in Amsterdam, the exiled Brethren naturally joined Collegiant circles. When Johann Crell Jr. graduated as a physician at the University of Leiden in 1674, he dedicated his dissertation to several people, some of them active in the Amsterdam College, such as the Doopsgezind-Mennonite physician Galenus Abrahamsz (1622-1706). ${ }^{44}$ According to a letter of Francke Jr., Abrahamsz was also involved

40 Lambour, "Daniel Zwicker" (see above, n. 21), 124.

41 Ibid., 128 and 131.

42 For more information on the history of the Amsterdam College until 1665, see Francesco Quatrini, Adam Boreel (1602-1665): A Collegiant's Attempt to Reform Christian Religion (Leiden, 2021), 84-120 and 163-192. For more information on the Collegiants in general, see Jacobus Cornelis van Slee, De rijnsburger collegianten (Haarlem, 1895); Leszek Kołakowski, "Dutch Seventeenth-Century Anti-Confessional Ideas and Rational Religion: The Mennonite, Collegiant, and Spinozan Connections," trans. and intro. by James Satterwhite, Mennonite Quarterly Review 64 (1990), 259-297 and 385-416; Andrew C. Fix, Prophecy and Reason: The Dutch Collegiants in the Early Enlightenment (Princeton, 1991); Wiep van Bunge, Spinoza Past and Present: Essays on Spinoza, Spinozism, and Spinoza Scholarship (Leiden, 2012), 51-66.

43 For De Breen, see Kot, Socinianism in Poland (see above, n. 5), 165-168; Peter G. Bietenholz, "Erasmus en het zeventiende-eeuws antitrinitarisme; het geval Daniel Zwicker and Daniel de Breen," Doopsgezinde Bijdragen 30 (2004), 103-124. For Knol, see Piet Visser, "Kritisch commentaar van een collegiantische kwelgeest: Twee manuscripten en een pamphlet van Jan Knol uit de jaren 1655-1659," Doopsgezinde Bijdragen 38 (2012), 285-35o. For Kuyper, see Aart de Groot, "Arcana atheism (1676): Frans Kuyper contra de ongodisten van zijn eeuw," Tijdschrift voor Nederlandse Kerkgeschiedenis 13 (2010), 97-109; Ruud Lambour, "De collegiant Frans Kuyper (ca. 1628-1691), zijn Joodse moeder en de relatie van zijn vader met de Joodse filosoof Uriel da Costa (1584-1640)," Doopsgezinde Bijdragen 42 (2016), 127140 .

Lambour, "Daniel Zicker” (see above, n. 21), 131-132. 
in the publication of the Bibliotheca fratrorum polonorum (the collection of Brethren writings published in Amsterdam in the late 166os), together with the Remonstrants Isaac Pontanus (1625-1710) and Arnold Poelenburg (16281666). ${ }^{45}$ The Brethren Benjamin Ladenbach asked the Collegiant Jacob Jansen Voogd (1630-1710) to be his best man when he married the Doopsgezind Sara van Bijler in $1667{ }^{46}$ Voogd was also a close acquaintance of Marcin Ruar Jr., as they participated in Collegiant meetings together. ${ }^{47}$ David Ruar too had friends among the Collegiants, while Johannes Crell Jr. was active in Collegiant circles in both Amsterdam and Rotterdam. ${ }^{48}$ Finally, despite his opposition to the freedom of prophesying as practiced by the Collegiants, and despite his controversy with Abrahamsz, Zwicker also had many ties with several Collegiants and it seems that he even organized his own meetings in the 167 os. $^{49}$

The relations established by the exiled Brethren with different nonconforming Protestant groups are clear evidence of the atmosphere of practical toleration characterizing Amsterdam in the mid-seventeenth century, proving how boundaries among confessions were quite blurred at the social and practical level. One might wonder whether this practical inter-confessionalism, in turn, favoured intellectual interrelations between these different groups. Focusing on the Collegiants, the next section reveals how the defence of religious tolerance was the common intellectual background between them and the Brethren, and how the Brethren were then influenced by the Collegiants' practices of freedom of prophesying and egalitarianism..$^{50}$

\section{Intellectual Crossovers between the Polish Brethren and the Dutch Collegiants}

When discussing the presence of anti-Trinitarians within the Amsterdam College, Jonathan Israel has rightly highlighted that many leading members among

45 Kis, "Enkele contacten" (see above, n. 13), 196.

46 Lambour, "Daniel Zicker" (see above, n. 21), 133-134.

47 Ibid., 125 .

48 Ibid., $127-128$ and $131-132$.

49 Ibid., $145^{-156 .}$

50 For the intellectual interrelations between the Brethren and the Remonstrants, see Martin Mulsow and Jan Rohls, eds., Socinianism and Arminianism: Antitrinitarians, Calvinists and Cultural Exchange in Seventeenth-Century Europe (Leiden, 2005); Luisa Simonutti, "Fausto Sozzini, gli arminiani e il socinianesimo nell' Olanda del Seicento," in Faustus Socinus and His Heritage, ed. Lech Szczucki (Krakow, 2016), 251-283. 
the Collegiants were not anti-Trinitarians. ${ }^{51}$ If one then thinks about the fact that anti-Trinitarianism was often regarded as unchristian, it might be surprising that the Brethren had been welcomed in Collegiant circles. The denial of the Trinity, however, was just one aspect of the Brethren's ideology. Advocacy for freedom of religion and tolerance was also an integral part of their thinking, and these concepts were also fundamental for all the Collegiants. Therefore, while many of them could hardly agree with the Brethren on the denial of the Trinity, they certainly found themselves in complete agreement when advocating for freedom of religion. In short, the defence of religious tolerance was the intellectual common ground that, together with the actual practices of toleration, certainly contributed to the friendly social relations between the Brethren and the Collegiants: neither of them regarded the denial of or the belief in the Trinity as a fundamental religious issue that should exclude someone from social relations. All the leading figures among the Brethren published works or devoted part of their writings to the defence of freedom of religion and tolerance. In what follows, I focus my analysis particularly on Johannes Crell's Vindiciae pro religionis libertate [A Vindication of Freedom of Religion] for two main reasons. Not only does it include all the main arguments developed by the Brethren in defence of freedom of religion, but it was also published four times between the late 1640s and 166os, including a Dutch translation. I have no doubts that the Collegiants knew this pamphlet very well. ${ }^{52}$

Crell's Vindiciae aims to show that Catholics and "heretics," a term that for Crell includes all those who disagree with the Roman Church, can live in peace with one another, even if they do not establish who is maintaining Christ's true doctrines. ${ }^{53}$ To reach this goal, Crell frequently refers to the difference between the political and the spiritual spheres. As religion belongs to the latter, political peace is possible even when different confessions coexist in the same commonwealth, and it is unlawful to use the temporal power to punish heretics or coerce them by force. Crell writes, for instance, that it is possible to give heretics a "right to civil indemnity and impunity" (jus tantum indemnitatis ac impunitatis civilis) without approving their heresies, because "approving is one thing, not coercing by force is another." 54 According to Crell, freedom of religion only requires that one refrain from forbidding the free exercise of other Chris-

51 Israel, Dutch Republic (see above, n. 11), 913.

$5^{2}$ In the following I will quote from the first Latin edition: [Johannes Crell], Iuni Bruti Poloni Vindiciae pro religionis libertate (Eleutheropoli, 1637). For the other versions, see Visser, Bibliographia Sociniana (see above, n. 39), 64-65, 81-82, and 95-96.

53 Vindiciae (see above, n. $5^{2}$ ), Letter to the Reader, [no page]. See also ibid., 42-43.

54 "Aliud est approbare, aliud vi non prohibere." Ibid., 15. 
tian faiths by force and, thus, that one do no harm to heretics. The Catholic Church can still oppose them, Crell writes, with "those spiritual weapons that she possesses in abundance, be they miracles or reasons and arguments." Even "a merely ecclesiastical condemnation" can still be used against heretics, "but not civil judgments, so that one does not proceed at the same time against their bodies, goods, or fame."55 The very nature of the Christian religion is contrary to coercion, according to Crell. ${ }^{56}$ Quoting Lactantius and Tertullianus, Crell emphasizes that religion is a matter of the will and thus men and women must freely choose their own faith. The use of force in religion only gives rise to hypocrisy and practices of Nicodemism, as "force cannot make someone think differently from what one thinks." 57

This kind of argument was not particularly new. It can be easily found in many different shapes in the works of all the champions of religious toleration from the sixteenth century onward. Other Brethren made similar statements, too. Commenting on Romans 13:4, for instance, Jonas Szlichtyng (1592-1662) argues that the Christian magistrate must indeed use his right to punish criminals or public enemies, but by no means is he allowed to punish heretics who respect civil laws and peace simply because they hold unconventional religious beliefs. "God did not wish that anyone should be compelled to the Christian truth and piety," Szlichtyng writes. He rather requires "voluntary worshippers." ${ }^{58}$ What perhaps distinguished the Vindiciae from other Brethren writings

55 "Relinquas etiam ecclesiae catholicae, ut eos armis spiritualibus, quibus polleat, sive miracula sint, sive rationes et argumenta, quam validissime possit, oppugnet, quin etiam, si ita placeat, censuris mere ecclesiasticis notet; mere, inquam, ecclesiasticis, non civilibus, ne simul in eorum corpora, fortunas aut famam grassetur." Ibid., 16 .

56 Ibid., 44 .

57 "Deinde quia hac ratione multi adiguntur, ut religionem simulant. Nam vis illa efficere non potest ut quis aliter sentiat quam sentit." Ibid. See also ibid., 29-30.

58 "Neminem enim Deus ad Chrisianam veritatem et pietatem adigi vult. Voluntarios requirit cultores." Jonas Szlichtyng, "Commentarius in epistolam Pauli Apostoli ad romanos," in Jonae Slichtingii a Bukowiek Commentaria posthuma, in plerosque Novi Testamenti libros, 2 vols. (Irenopoli, post 1656), 301-302. Szlichtyng also developed a whole section discussing the persecution of heretics and freedom of religion in his reply to the Lutheran theologian Balthasar Meisner, where Szlichtyng made use of arguments quite similar to Crell's. See Jonas Szlichtyng, Quaestiones duae: una num in evangelicorum religione dogmata habeantur quae vix ullo modo permittant, ut qui eas amplectatur, nullo in peccato perseveret? Altera num in eadem religione concedantur Christi legibus inconcessa? Contra Balthasarem Meisnerum, S. theologiae doctorem et in academia Witterbergensi professorem publicum (Raków, 1636), 46o-495. For more information on the Brethren and religious tolerance, see Fiorella Pintacuda de Michelis, Socinianesimo e tolleranza nell'età del razionalismo (Firenze, 1975); Luisa Simonutti, "Resistance, Obedience, and Toleration: Przypkowski and Limorch," in Socinianism and Arminianism (see above, n. 50), 196-204. 
on religious tolerance is its versatility. Although Crell conceived his pamphlet as defending peace between the Roman Catholics and all the other Christian denominations, a close examination reveals that Crell used the term "Catholic" as a loose concept that can be applied easily to other mainstream churches in several European countries. This explains why the Vindiciae was translated into English, Dutch, and French, and published in countries where Catholics were not the persecuting denomination, but the persecuted one. For instance, when refuting the Catholics' argument that the very presence of heresies is a danger for the commonwealth, Crell highlights that such an argument can also be used against Catholics in those commonwealths where they represent a minority, such as the Dutch Republic. "Everyone thinks that they feel, perceive, and believe most clearly about religion, and a Catholic is no less a heretic for a heretic, than a heretic is for a Catholic," Crell concludes. ${ }^{59}$

Moreover, in key passages urging his readers to practice tolerance or to allow freedom of religion, it is noteworthy that Crell did not use the term "Catholic," but rather the much broader term "Christian," while in others he also seems to extend freedom of religion to non-Christian faiths. For instance, when opposing the punishment of heretics, Crell concludes by asking, "who among Christians would be so fierce and cruel that he would think to use violence against them [heretics], instead of patience and mildness?"60 Similarly, after proving that freedom of religion does not mean that one accepts heretical doctrines, Crell concludes: "It is legitimate for Christians to grant those who favour and defend impious errors a right to indemnity and impunity."61 One might wonder whether even non-Christians can be included among those "who favour and defend impious errors."

There are at least three other passages that strengthen such a hypothesis. At the beginning of the last chapter of Vindiciae, Crell writes that "nature and common reason teach that anyone must seek peace with as many people as possible, especially with those who much desire and demand such a peace." ${ }^{\prime 2}$ This passage is quite similar to the conclusion of the first chapter, where Crell states: "Whoever seeks a civil society with others to the utmost

59 "Ac praeterea, quisque se putat optime de religione sentire ac credere: et catholicus non minus haeretico est hareticus, quam haereticus catholico." Vindiciae (see above, n. $5^{2}$ ), 42.

6o "Quis christianorum hominum tam ferocis, tamque crudelis erit animi, ut saevitia erga eos potius quam patientia ac mansuetudine utendum censeat?" Ibid., 56 . For a similar passage, see also ibid., 24-25.

61 "Sequitur etiam, licere christianis jus hujusmodi indemnitatis ac impunitatis concedere iis, qui errores impios fovent ac defendunt." Ibid., 18.

62 "Quanquam et alias natura ratioque communis docet: quemvis pacem debere colere cum omnibus, cum quibus possit, praesertim valde cupientibus ac flagitantibus." Ibid., 43. 
of their ability, and does not disturb the peace and tranquillity of others, cannot be excluded by any right from civil society and by no means peace should be denied to them." ${ }^{63}$ The indefinite pronouns "anyone" (quemvis) and "whoever" (quicunque) seem to broaden Crell's argument beyond the boundaries of Christianity. Civil peace should and can be sought, regardless of differences of faith. Indeed, Crell admits that religion is a useful means to unite people within a commonwealth, but he denies that "difference of religion divides people's hearts so much that civil concord and mutual benevolence among citizens cannot withstand that dissension." ${ }^{64}$

The Collegiants certainly agreed with these arguments for a boundless freedom of religion for all the Christian denominations and perhaps, even for nonChristian religions. Indeed, all the chief spokespersons among the Collegiants in Amsterdam and in other Dutch cities made the defence of religious tolerance one of their main tenets. ${ }^{65}$ As a comprehensive and comparative study between the Collegiant and the Brethren arguments for tolerance is lacking, it is hard to tell if and how far the latter might have influenced the former. Due to their many social relations and their common views on the topic, I suggest that such a study would likely produce fruitful outcomes. To provide evidence on how the social interactions between the Collegiants and the Brethren resulted in intellectual interrelations between the two groups, one can focus on three other essential aspects of Collegiant thinking, that is, freedom of prophesying, anticonfessionalism, and egalitarianism. ${ }^{66}$ Such concepts were regularly practiced in the Collegiants' meetings, where no profession of faith was required and

63 "Quicumque societatem civilem pro virili cum aliis colunt, nec pacem, ac tranquillitatem aliorum turbant, illi a societate civili excludi nullo jure possunt, nec pax illis nullo modo deneganda est." Ibid., 14.

64 "Sed ilud tamen negamus, religionum diversitate ita omnino distrahi populi animos, ut civilis concordia, et mutua civium benevolentia constare in illo dissensu non possit." Ibid., 36.

65 Fix, Prophecy and Reason (see above, n. 42), 113-132; Francesco Quatrini, "Adam Boreel and Galenus Abrahamsz. against Constraint of Consciences: Seventeenth-Century Dissenters in Favor of Religious Toleration," History of European Ideas 44 (2018), 1127-1140. While the Collegiants seem not to have shared common views on whether to extend religious tolerance to non-Christian religions, they were certainly interested in local Jewish communities, especially in Amsterdam, where members of the College such as Adam Boreel and Pieter Balling had friendly relationships with Jews or former Jews such as Menasseh ben Israel and the philosopher Baruch Spinoza. For more information, see Michael Driedger, "Spinoza and the Boundary Zones of Religious Interaction," The Conrad Grebel Review 25 (2007), 21-28; and Quatrini, Adam Boreel (see above, n. 42), 61-78 and 153-162.

66 For more information on the Collegiants' freedom of prophesying, see Francesco Quatrini, "Adam Boreel on Collegiant Freedom of Speech," Journal of the History of Ideas 8o (2019), $511-531$. 
where all participants could equally express their own opinion on the matters under discussion. No doubt the Brethren participating in the Collegiants' meetings in Amsterdam enjoyed such a freedom as well. These practices influenced the Brethren living in Amsterdam, who soon began to defend those three concepts. This is what can be concluded from a private letter sent by Adam Francke Jr. to the German Unitarian Church in Transylvania in $1667,{ }^{67}$ as well as from the foreword to the new edition of the Racovian Cathechism - the Brethren's confession of faith - published in Amsterdam sometime after $1667 .{ }^{68}$

Francke wrote his letter to free himself from false accusations that had been reported to the Unitarian Church of Cluj in Transylvania. ${ }^{69}$ In doing so, however, Francke admitted that he was not sure whether to return to Cluj or to remain in the Netherlands. While explaining the reasons for his doubts, Francke reveals how Collegiant practices had influenced him. He writes that the main reason why he was so hesitant to return is that "the Spirit of Dordrecht rules also among you," which obliges everyone "to subscribe to your confessions" and forbids anything from "disagreeing in any way with them."70 Francke attacks the oath required from those who want to join and teach the "Unitarian religion" (Unitariam religionem), an oath that obliges everyone to promise that they will remain faithful to the Unitarian faith. Francke then lists some doctrines that "overturn the dogmas of the Christian religion, rather

67 Francke's letter has been published and translated into Dutch by Atilla Kis: Kis, "Adam Francke" (see above, n. 34), 202-227. In the following, I will quote and translate from the Latin text.

68 Catechesis ecclesiarum polonicarum, Unum Deum Patrem, illiusque filium unigenitum, una cum spiritu sancto ex S. Scriptura confitentium. Anno Christi 1609 in lucem primum emissa, et post per viros aliquot in eodem regno correcta. Iterumque interpositis compluribus annis a Johanne Crellio Franco ac nunc tandem a Jona Schlichtingio a Bucowiec recognita, ac dimidia amplius parte aucta (Irenopoli, post 1659). According to the Bibliographia Sociniana, the second edition of the Racovian Cathechism was published in 1665. Francke's letter, however, proves that the Catechism had not been published yet in 1667. Indeed, Francke writes: "The most important Racovian Catechism, revised and enlarged by Johannes Simplicius (that is, Szlichtyng), already sweats under the press and soon, I hope, should be exhibited for everyone's eyes" ["Catechesis Racoviana major a Joanne Simplicio (qui Slichtingius est) revisa et aucta jam sudat sub prelo, brevi, ut spero, omnium oculis exponenda"]. Kis, "Adam Francke" (see above, n. 34), 210.

69 Ibid., 202.

70 "Prima itaque ac princeps illa est, quod spiritus ille Dordracensus inter vos quoque regnet, qui vestris placitis, vel ut clarius loquar vestris confessionibus subscribere nec ab iis ullo modo discrepandum esse jubet quoque quivis." Ibid., 203. Note: I suspect that "quivis" is a transcription error and it should read as "quidvis," but since I have not been able to check the original manuscript, this supposition will have to remain unresolved for the moment. 
than make them firm," and that "also eliminate Christian freedom."71 Among these, Francke mentions the fact that "speaking in the Church is permitted ... only to one preacher," that "it is not allowed to contradict, ask, investigate, and examine prelates, and this in presence of hearers," and that "it is not legitimate to have private colleges." ${ }^{72}$ Moreover, when justifying himself for not having addressed the Unitarian ministers as "venerable and most esteemed men," Francke makes reference to those egalitarian beliefs so common among the Collegiants, writing that "there are no male or female, nor lords or serfs among Christians." "We all have the same right of God's children," Francke writes. ${ }^{73}$ Anti-confessionalism, freedom of prophesying, freedom to hold religious meetings, and egalitarianism: these were the same values that many Collegiants practiced in their meetings and promoted over the years.

Opposition to confessionalism, freedom of prophesying, and egalitarianism are also the main concepts put forward in the foreword to the new edition of the Racovian Catechism. Aware that anti-confessionalism and the publication of a catechism are clearly at odds, the editors justify the writing and publication of the Racovian Catechism. They state that, while other Christian confessions aim to coerce people's consciences and require an oath from their followers, the Brethren did not pursue such goals when writing their Catechism. Rather, they leave each Christian free to follow his own judgment in religious matters. ${ }^{74}$ "This is that golden freedom of prophesying," the editors write, "that the Holy Scripture of the New Testament recommends us," the same freedom on which the Apostolic Church was founded. ${ }^{75}$ Then, the editors proceed to reproach all those who deprive their fellow Christians of this freedom, who claim the right to judge and interpret the Scripture only for themselves. ${ }^{76}$ They have forgotten that "Christ is our only ruler," that "we are all brethren," and that "authority

71 "Etsi alias in multis disceptet animus, multaque videam in ea tueri doceri et defendi quae Christianae religionae dogmata evertunt potius quam stabiliunt, quoque Christianam libertatem tollunt." Ibid.

72 "Talia sunt ... quod uni et soli concionatori ... in ecclesia loqui permissum sit: quod non liceat contradicere, quaerere, indagare et examinare praelata, idque in auditorium praesentia, quod nulla liceat habere collegia privata." Ibid.

73 "Ignoscite etiam quod reverendorum aut amplissimorum virorum nomine vos non compellem, quoque vester alumnus me vobis parem facere videar. Prius enim sacris literis N. Testamenti clare prohibitum video: posterius ... non est inter Christianos mas vel foemina non dominus vel servus. Omnes idem jus filiorum Dei habemus." Ibid., 206.

74 Catechesis ecclesiarum polonicarum (see above, n. 68 ), ${ }^{*} 3^{\mathrm{r}}$.

75 "Haec enim est aurea illa prophetandi libertas, quam Sacrae Literae Novi Instrumenti nobis impense commendat, et in qua apostolorum primitiva ecclesia nobis exemplo suo facem praetulit." Ibid.

76 Ibid., ${ }^{*} 3^{\mathrm{v}_{-} *} 4^{\mathrm{r}}$. 
and lordship over another's conscience have been granted to none among us."77 Indeed, according to the editors, no one can prove themselves to have been provided with the gifts of the Holy Spirit and, thus, no one can prove themselves to be a true prophet as described in Scripture. ${ }^{78}$ This also was a typical argument among the Collegiants in order to favour Christian egalitarianism and to attack ecclesiastical authority.

\section{4}

\section{Conclusion}

In conclusion, solid evidence proves there were many social and intellectual relationships between the exiled Polish Brethren and other Christian denominations in Amsterdam. The history of the Brethren on Dutch soil dates back to the end of the sixteenth century, but I have argued that significant numbers of anti-Trinitarian exiles in Amsterdam can be found only from the late 165os onward. Although scattered Polish Brethren can be traced in the United Provinces before the mid-seventeenth century, the concern previously expressed by the Dutch Reformed Church and factions of the civil authorities, especially around 1638 , had no actual basis. ${ }^{79}$ It is true, however, that the Brethren had established many contacts with Dutch intellectuals, especially among the Remonstrants, well before 1658 , when the Brethren were officially banished from the Polish-Lithuanian Commonwealth. Moreover, the Brethren's ideas and books were spreading in Dutch society from the early 1610 , and in the 165 os there were Collegiants who openly professed their anti-Trinitarianism. If one adds that leading members of the Brethren such as Daniel Zwicker, who was related to all the major Brethren families, settled in Amsterdam in 1657, it can be easily understood why higher numbers of Brethren moved to the Netherlands after they were forced to leave their homeland. Relying on family relations, many settled in Amsterdam, where they found protection within the Remonstrant Church, and where they established

\footnotetext{
77 "Cur non meministis, unicum duntaxat esse magistrum nostrum, cui ista competent Christum: nos vero omnes fratres esse, quorum nulli potestas ac dominium in conscientiam alterius concessum est?" Ibid., * $4^{\mathrm{r}}$. See also: ${ }^{* *} 2^{\mathrm{v}_{-} * *} 3^{\mathrm{r}}$.

78 Ibid., * $4^{\mathrm{v}-* *} 1^{\mathrm{v}}$.

79 In the 1630s, another famous Brethren in the Dutch Republic was Christopher Arciszewski (Arcissevius), a Polish commander who served the West India Company in Brazil, receiving a medal from the States of Holland for his services. See Robert Wallace, Antitrinitarian Biography: Or Sketches of the Lives and Writings of Distinguished Antitrinitarians, 3 vols. (London, 1850), 3: 107-110.
} 
new relationships or strengthened older ones with other religious minorities, such as the Doopsgezinden and the Collegiants.

One might wonder whether these social interactions gradually led to intellectual interrelations among these groups or whether a pre-existing intellectual common ground predisposed the groups toward such relationships. Focusing on the Collegiants, I have suggested that both these hypotheses are likely true. Brethren arguments for freedom of religion, as developed, for instance, by Johannes Crell in the Vindiciae pro religionis libertate, undoubtedly appealed to the Collegiants, who wrote many pleas for religious tolerance and practiced toleration in their meetings. These common views on religious tolerance certainly encouraged friendships between the Brethren and the Collegiants who, except for a few individuals, were not anti-Trinitarians. At the same time, these personal relations led to further intellectual crossovers. Indeed, the freedom of prophesying and the egalitarianism practiced by the Collegiants in their meetings influenced the Brethren living in Amsterdam, a claim that is supported by the letter sent by Adam Francke Jr. and the foreword to the second edition of the Racovian Cathechism.

To be sure, the emphasis of the Brethren in Amsterdam on anti-confessionalism, freedom of prophesying, and egalitarianism might very well be a natural development of the views on freedom of religion developed by the Brethren's forefathers. Indeed, Atilla Kis has revealed that Francke's own church in Transylvania was already practicing a limited freedom of prophesying. ${ }^{80}$ Nevertheless, I argue that the Brethren's relations with the Collegiants and the kind of freedom of prophesying and egalitarianism the latter practiced influenced the further course of the Brethren's views. It is not by chance that those three concepts became essential for the Brethren in Amsterdam, so much so that they represent the framework of the foreword to their Catechism. Therefore, rather than examining the social and intellectual histories of these religious groups in isolation from one another, regarding them as interrelated and interdependent is more fruitful. This is especially true if one considers that renowned intellectuals, such as Baruch Spinoza, Jean Le Clerc (1657-1736), John Locke (1632-1704), and Pierre Bayle (1647-1706), had many friendly relations with the exiled Brethren, as well as with the Remonstrants, Doopsgezinden, and Collegiants. Further studies of how social relations promoted intellectual crossovers and, at the same time, how these promoted social relations might then provide a broader and more comprehensive picture of that fundamental period called the Early Enlightenment. 